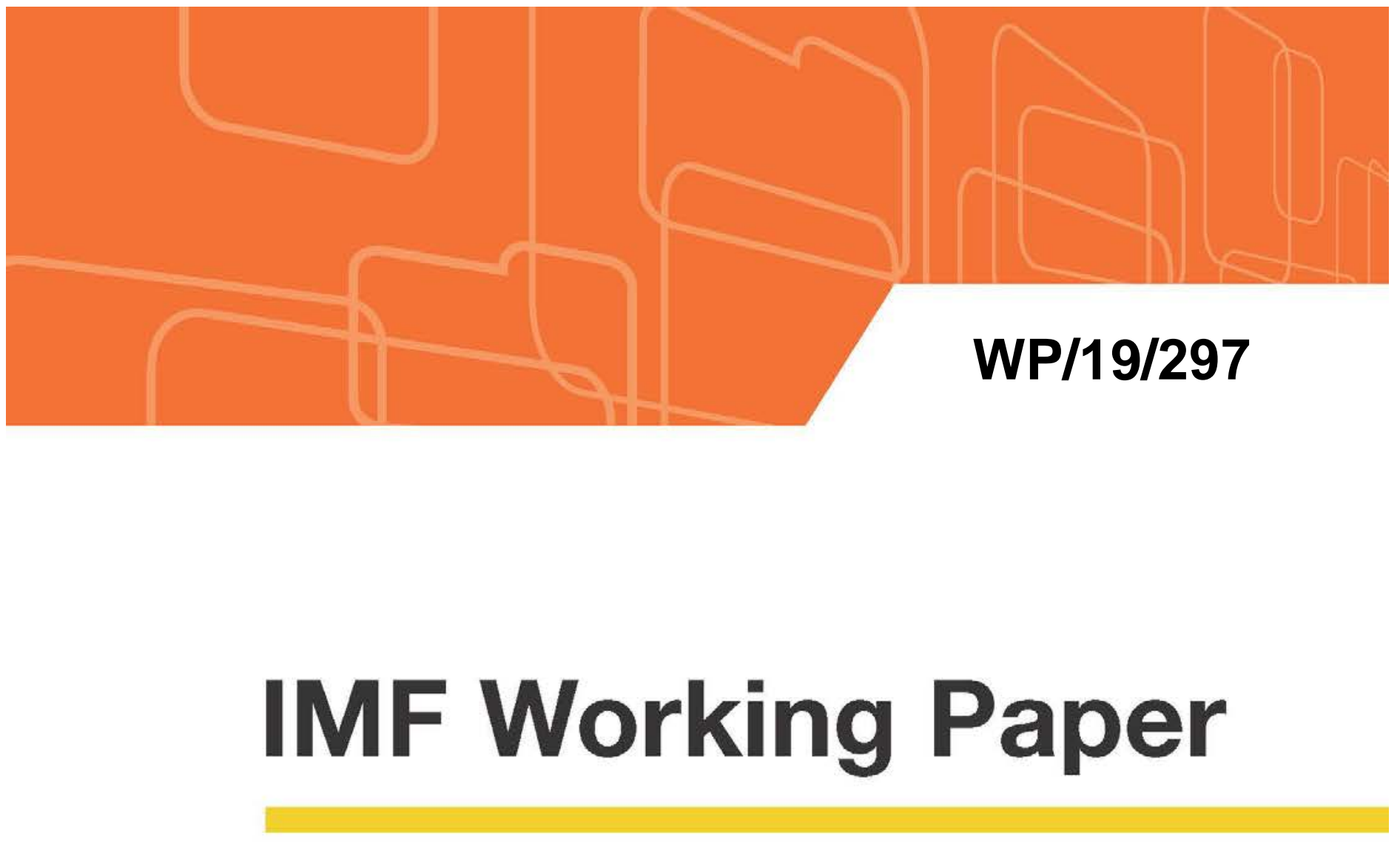

\title{
Inflation and Public Debt Reversals in Advanced Economies
}

by Ichiro Fukunaga, Takuji Komatsuzaki, and Hideaki Matsuoka

IMF Working Papers describe research in progress by the author(s) and are published to elicit comments and to encourage debate. The views expressed in IMF Working Papers are those of the author(s) and do not necessarily represent the views of the IMF, its Executive Board, or IMF management.

$$
\text { I N T E R N A T I O N A L M O N E T A R Y F U N D }
$$




\title{
IMF Working Paper
}

Strategy, Policy, and Review Department

Inflation and Public Debt Reversals in Advanced Economies

Prepared by Ichiro Fukunaga, Takuji Komatsuzaki, and Hideaki Matsuoka1

Authorized for distribution by Rupa Duttagupta

December 2019

\begin{abstract}
IMF Working Papers describe research in progress by the author(s) and are published to elicit comments and to encourage debate. The views expressed in IMF Working Papers are those of the author(s) and do not necessarily represent the views of the IMF, its Executive Board, or IMF management.
\end{abstract}

\begin{abstract}
This paper quantitatively assesses the effects of inflation shocks on the public debt-to-GDP ratio in 19 advanced economies using simulation and estimation approaches. The simulations based on the debt dynamics equation and estimations of impulse responses by local projections both suggest that a 1 percentage point shock to inflation rate reduces the debt-to-GDP ratio by about 0.5 to 1 percentage points. The results also suggest that the impact is larger and more persistent when the debt maturity is longer, but the difference from the benchmark case is not significant. These results imply that modestly higher inflation, even if accompanied by some financial repression, could reduce public debt burden only marginally in many advanced economies
\end{abstract}

JEL Classification Numbers: E31, E63, H63

Keywords: Inflation, public debt, financial repression, advanced economies

Author’s E-Mail Address: fukunaga.ichiro29@gmail.com; tkomatsuzaki@imf.org; hmatsuoka@worldbank.org

\footnotetext{
1 The authors are grateful to Rupa Duttagupta, Vikram Haksar, Ali Abbas, Paolo Dudine, Takuma Hisanaga, Daniela Marchettini, Hélène Poirson Ward, Narayan Suryakumar, seminar participants at the IMF, and other colleagues in the IMF and the World Bank for helpful comments and discussions. The views expressed in this paper are those of the authors and do not represent those of the organizations they work for.
} 


\section{INTRODUCTION}

Public debt in advanced economies is still high ten years after the global financial crisis. As of 2017, the debt-to-GDP ratios in advanced economies have plateaued since 2012 above 105 percent of GDP, a level not seen since World War II, and are expected to fall only marginally over the medium term (IMF, 2018). This high government debt is a cause for concern not only because it leads to vulnerability to rollover risks but also because it leaves limited room for countercyclical policies and could be a drag on long-term growth. ${ }^{2}$

A higher inflation is one of the potential channels to reduce debt burden. ${ }^{3}$ Historically, higher inflation contributed to public debt reversals after the World War II, especially when accompanied by "financial repression," in which real interest rates of the government borrowing are contained at below-market levels due to government regulations or institutional factors (Reinhart and Sbrancia, 2015). Currently in many advanced economies, inflation remains low despite years of accommodative monetary policies, economic growth has also been low to moderate, and fiscal consolidation has been slow, leading to a continuously high debt-to-GDP ratio. Following up on early calls for pursuing a higher inflation (Rogoff, 2013, Sims, 2016), revisiting the question regarding whether a higher inflation could contribute to a meaningful reduction in public debt without damaging macroeconomic stability remains relevant. This paper addresses this debate by empirically estimating the effect of inflation shocks on public debt in advanced economies.

We take two approaches to address our main question. First, we use a simulation approach, updating and expanding a previous study based on an extension of the standard debt dynamics equation (Akitoby et al., 2014), assuming that an inflation shock affects public debt-to-GDP ratio only through outstanding fixed-rate, long-term debt. Second, we adopt an estimation approach based on the local projection method, to estimate impulse response functions to inflation shocks. In both approaches, we also examine how a lower interest rate, possibly due to financial repression, could change the effectiveness of an inflation shock on the public debt. In particular, we check whether and by how much longer debt maturity or less frequent rollover could make the effects of an inflation shock larger and more persistent by keeping the longterm interest rate lower even after an inflation shock.

Our simulations suggest that a temporary 1 percentage point shock to inflation rate reduces the public debt-to-GDP ratio by about 0.7 percentage points on average across 19 advanced economies, while the differences across these countries largely depend on the initial level of debt and the debt rollover ratio. Our estimation results suggest that a temporary 1 percentage point inflation shock reduces the debt-to-GDP ratio by around 1 percentage point on impact. As discussed in the next section, these results are broadly in line with recent studies. Moreover,

\footnotetext{
${ }^{2}$ Blanchard (2019) explores the argument that the welfare cost of high public debt could be low in the context of low interest rates and therefore the public debt may not have to be reduced hastily, while acknowledging the potential counterarguments. The current paper does not address this ongoing debate.

${ }^{3}$ Best et al. (2019) surveys a broader set of policy options for public debt reductions, including fiscal consolidation, growth-enhancing policies, monetary policy, and financial repression, and makes assessments of each option.
} 
we find that, in both approaches, the effect of an inflation shock is larger and more persistent when the debt maturity is longer or the debt rollover is lower. However, the difference from the benchmark case is not necessarily large because the long-term interest rates and debt rollover ratios in the benchmark case are already low. These results imply that modestly higher inflation, even if accompanied by some financial repression, could reduce public debt burden only marginally in many advanced economies.

We focus on advanced economies and assume that a temporary inflation shock, such as a temporary overshooting of the inflation target, does not affect a central bank's credibility and monetary policy framework. ${ }^{4} \mathrm{We}$ also assume that the inflation shock is not correlated with other types of shocks, such as growth shocks or fiscal policy shocks. With these in mind, we use a larger sample of 19 advanced economies compared with previous studies on the effects of inflation on public debt. Other features of our analysis include the combination of simulation and estimation approaches and consideration of financial repression cases in both approaches. Moreover, our estimation approach attempts to add more granularity and robustness relative to existing studies by distinguishing long and short- maturities, identifying the inflation shock in multiple ways, and running regressions at different frequencies.

The remainder of the paper proceeds as follows. Section II briefly reviews the literature on the simulation and empirical analysis of the effects of inflation shocks on public debt. Section III presents our simulation approach, and Section IV presents our estimation approach. Section V concludes.

\section{LITERATURE REVIEW}

Table 1(a) summarizes recent studies on the effects of inflation shocks on public debt using simulations. The closest approach to ours is Akitoby et al. (2014), where the effects of a persistent inflation shock that raises inflation to 6 percent for the next five years on the public debt-to-GDP ratio is simulated using the IMF's World Economic Outlook (WEO) data for G7 countries. Compared to them, we use updated WEO data and expand sample countries. We also take account of the debt rollover ratio more explicitly and examine the effects of a temporary inflation shock as well as a persistent shock. Hilscher et al. (2017) and Equiza-Goñi (2016) also simulate the effects of inflation on public debt-to-GDP ratio based on the debt dynamics equation, but they use more detailed government bonds data (the former also uses option price data to estimate the distribution of inflation risks) focusing on the US and a few euro area countries, respectively. Aizenman and Marion (2011) simply use the US debt maturity in 2009 to approximate the effects of persistently higher inflation. End et al. (2015) uses a model of fiscal account dynamics for the euro area to simulate the effects of persistent inflation/disinflation shocks. Krause and Moyen (2016) uses a New Keynesian dynamic general equilibrium model with an imperfectly observed inflation target and simulate the

\footnotetext{
${ }^{4}$ In some countries (most notably Japan but also euro area and the U.S.), central banks hold substantial amount of long-term government debt, and thus the debt-reducing effect of an inflation shock is partially offset by the loss of central banks. We assume that the loss of central banks caused by an inflation shock in our analysis is not so substantial to affect their credibility and monetary policy frameworks.
} 
effects of shocks to the inflation target. While our simulation approach is different from these studies and uses a larger sample of countries, our results on the effects of a persistent inflation shock are broadly in line with theirs.

A few recent empirical studies on the effects of inflation shocks on public debt are summarized in Table 1(b). As far as we know, Afonso and Jalles (2019) is the only one that uses the local projection method as we do. While they use historical data before the World War I and focus on a deflationary dummy, their results from the local projection are broadly in line with ours. Quantitatively, however, their results and End et al. (2015)'s results from panel regression, however, are smaller than ours. Cherif and Hasanov (2018) estimate a VAR model with the debt dynamics equation using the US data, and their estimated impact of an inflation shock on debt-to-GDP ratio is comparable to ours.

Besides the above-cited recent studies using simulation or estimation approach comparable to ours, there is a long strand of literature on the link between inflation and public debt. Using detailed historical data of public debt, Hall and Sargent (2011) and Abbas et al. (2011) provide an accounting decomposition of the evolution of public debt and calculate the contribution of inflation and find that inflation was not a consistent source of public debt reduction, but played an important role in certain periods, such as post-war U.S. until the 1960s. Giannitsarou and Scott (2008) explore the implications of rising public debt for inflation based on an accounting exercise of public debt. The literature on the fiscal theory of price level, including Cochrane (2011) and Davig et al. (2011), explores the theoretical possibility that high level of public debt may lead to higher inflation. Doepke and Schneider (2006) studies the impact of an inflation shock on wealth distribution across private holders of public debt.

\section{Simulation ApProACH}

\section{A. Methodology}

\section{Debt dynamics equation}

Our simulation approach is based on the following framework that extends the standard debt dynamics equation by making explicit the exogenous inflation shock and making a distinction between short and long-term debt.

Abstracting from the stock-flow adjustment, debt dynamics can be expressed as:

$$
b_{t+1}=-s_{t+1}+b_{t} \frac{1+i_{t+1}}{\left(1+g_{t+1}\right)\left(1+\pi_{t+1}\right)}
$$

where $b_{t}, s_{t+1}, i_{t+1}, g_{t+1}, \pi_{t+1}$ are the debt-to-GDP ratio, primary surplus-to-GDP ratio, nominal interest rate, real GDP growth, and inflation, respectively. 
Next, make a distinction between short-term debt $\left(b_{t}^{S}\right)$ and long-term debt $\left(b_{t}^{L}\right)$. Furthermore, distinguish between the long-term debt issued in year $\mathrm{t}\left(b_{t}^{L, n e w}\right)$ and the long-term debt that was issued prior to year $\mathrm{t}\left(b_{t}^{L, \text { old }}\right)$. With these breakdowns, the debt dynamics equation is $b_{t+1}=-S_{t+1}+b_{t}^{S}\left[\frac{1+i_{t+1}^{S}}{\left(1+g_{t+1}\right)\left(1+\pi_{t+1}\right)}\right]+b_{t}^{L, \text { old }}\left[\frac{1+i_{t+1}^{L, \text { old }}}{\left(1+g_{t+1}\right)\left(1+\pi_{t+1}\right)}\right]+b_{t}^{L \text {,new }}\left[\frac{1+i_{t+1}^{L, \text { new }}}{\left(1+g_{t+1}\right)\left(1+\pi_{t+1}\right)}\right]$

In the baseline, the debt to GDP ratio is recursively obtained using this equation and matching WEO projections, while assuming that the government chooses to issue $b_{t}^{S}$ and $b_{t}^{L, n e w}$ each year to keep the maturity structure of the public debt unchanged.

Now, suppose there is an unexpected inflation shock of size $\Delta \pi_{t}$ in year $t$. While the nominal interest rates on the short-term debt and long-term debt that is issued in year $t$ are adjusted upward for the new, higher inflation, the nominal interest rate on the long-term debt that was issued prior to year $t$ is not adjusted as it is predetermined. We assume that the change in inflation does not affect growth or primary balance. ${ }^{5}$ Consequently, the debt-to-GDP ratio in year $t+1$ is now the following:

$$
\begin{aligned}
& b_{t+1}=-S_{t+1}+b_{t}^{S}\left[\frac{1+i_{t+1}^{S}+\Delta \pi_{t}}{\left(1+g_{t+1}\right)\left(1+\pi_{t+1}+\Delta \pi_{t}\right)}\right]+b_{t}^{L, \text { old }}\left[\frac{1+i_{t+1}^{L, \text { old }}}{\left(1+g_{t+1}\right)\left(1+\pi_{t+1}+\Delta \pi_{t}\right)}\right] \\
& +b_{t}^{L, \text { new }}\left[\frac{1+i_{t+1}^{L, \text { new }}+\Delta \pi_{t}}{\left(1+g_{t+1}\right)\left(1+\pi_{t+1}+\Delta \pi_{t}\right)}\right]
\end{aligned}
$$

$b_{t}$ : debt-to-GDP ratio ( $S$ : short-term, $L$,old: long-term old, $L$,new: long-term new)

$s_{t}$ : primary surplus to GDP ratio, $i_{t}$ : Nominal interest rate ( $S$ : short-term, $L$ : long-term)

$g_{t}$ : real GDP growth rate, $\pi_{t}$ : Inflation rate (baseline)

The debt-reduction effect of an inflation shock $\left(\Delta \pi_{t}\right)$ is measured by the difference in the debtto-GDP ratio in the baseline scenario and the inflation shock scenario. Thus the inflation shock affects the debt-to-GDP ratio $\left(b_{t}\right)$ only through the decrease in the real interest rate. This decrease in real interest rate applies only to the long-term debt which had been issued prior to the inflation shock (3rd term in the right-hand side). The size of the 3rd term over time, which is dependent on the initial level of $b_{t-1}^{L, \text { old }}$ and how quickly it is rolled over, are crucial for the size of debt reduction. For a given level of initial debt-to-GDP ratio and given size of inflation shock, the higher the share of the medium-to long-term debt and the lower the roll-over ratio, more debt remain in the 3rd term and thus the debt-reduction effect is larger.

\footnotetext{
${ }^{5}$ In practice, inflation could affect primary surplus or growth. See Afonso and Jalles (2019) and End et al. (2015) for an example of the former and Khan and Senhadji (2001) for an example of the latter. Since the direction or magnitude is not clear, we opted for a simplified assumption.
} 


\section{Data}

19 advanced economies are included in the sample. Country coverage is defined by data availability, especially data on debt structure. ${ }^{6}$ Macro variables over 2018-22, such as $b_{t}, s_{t}$, $g_{t}$, and $\pi_{t}$ are drawn from the IMF WEO Projection (April 2018) to construct the baseline scenarios. $\pi_{t}$ is the GDP deflator so that the nominal GDP growth can be decomposed into $g_{t}$ and $\pi_{t}$. Share of short-term and medium and long-term debt at the start of the simulation comes from SNA data on short/long debt ratio (assumed to be constant). The rollover ratio that controls the trajectory of the medium-to-long-term debt comes from April 2018 Fiscal Monitor for 2018-20. For 2021-22, the rollover ratio is assumed to be identical to 2020.

We consider a temporary, 1 percentage point shock to inflation in 2018 only, to be comparable with the impulse response function estimated in section IV. ${ }^{7}$

\section{B. Responses to temporary inflation shock}

\section{Benchmark case}

Results are shown in Figure 1. It shows the percentage deviations of the debt-to-GDP ratio from the baseline levels in response to a temporary 1 percentage point shock to inflation, or a one-time shift in price level. Deviation is the largest for Japan, about 2 percentage points, and the smallest for Czech Republic. On average, the deviation is about 0.7 percentage points. Reflecting the temporary nature of the shock, the debt reduction effect is concentrated in the first year.

\section{Differences across countries}

The difference in the size of the initial debt reduction across countries is mostly explained by the initial debt level, as the debt reduction is measured in terms of percent of GDP (Figure 2). Most of the variation in the size of debt reduction disappears when the initial level of debt-toGDP ratio is set at 84 percent, average for the sample (panel (a)). Since countries with high initial debt tend to also have high long-term debt that is affected by the inflation shock, a higher initial debt level is associated with the size of debt reduction (panel (b)). However, the rollover ratio also matters given the same level of initial public debt. Once we control the initial debt level, there is a clear relationship between the rollover ratio and the size of debt reduction, and in countries where the rollover ratio is higher such as Czech and Hungary, the effect is smaller (panel (c)). This is because the interest rates on a larger portion of the total public debt in these

\footnotetext{
${ }^{6}$ Austria, Belgium, Canada, Czech Republic, Denmark, Finland, France, Germany, Hungary, Ireland, Italy, Japan, Netherlands, Poland, Portugal, Spain, Sweden, United Kingdom, and United States. Some countries (Australia, Greece, and Norway) are excluded because we use government bond yields as the interest rates in our estimation approach and the share of their debt securities (against loans) in these three countries were low in certain periods.

${ }^{7}$ We also consider a persistent shock that raises inflation to 6\% over 2018-22, following Akitoby et al. (2014), and find that the results are broadly comparable with those in their paper. Summary results are in the appendix.
} 
countries are adjusted upward in response to the inflation shock and therefore the corresponding proportion of debt-to-GDP ratio is not affected by the inflation shock.

\section{Financial repression cases}

One of the possible factors that may cause a low roll-over ratio is so-called "Financial Repression”. Financial repression is defined as the state when policy interest rates are not responsible to inflation and are maintained at levels lower than market rates owing to regulation or institutional factors. This could include caps on interest rates, central banks' reserve requirement, and captive domestic investors who are forced to facilitate direct credit to the government (Reinhart and Sbrancia, 2015).

As an extreme case of financial repression, let us consider the case in which all long-term interest rates are unresponsive to the shock, inclusive of the long-term debt that is issued after the inflation shock. In this case, the public debt response is a little larger than the benchmark case without financial repression (Figure 3). However, the additional effect is small, only about 0.1 percent of GDP, because the rollover ratio in the benchmark case is already small (13\% on average) and the shock is only temporary.

Another financial repression case is a negative interest rate shock case, in which an additional -1 percentage point shock to the long-term interest rate occurs at the same time as the 1 percentage point inflation shock. This combined shock is a -2 percentage point shock to the real interest rate. However, the interest rate shock is subject to the zero lower bound. In a country where the rate is already very low and close to zero, this additional shock is less than 1 percentage point. Then the responses to the combined shock are larger but not doubled from the benchmark case because of the zero lower bound. The additional debt reduction effect from this shock is about 0.5 percent of GDP.

In both cases, the effect of a given size of inflation shock on public debt becomes larger but the difference from the benchmark case is not necessarily large. ${ }^{8}$

\section{Estimation Approach}

\section{A. Methodology}

\section{Estimation method and specification}

In our estimation approach, we employ the Jordà (2005) local-projections method which has been widely used for estimating the impulse response function (IRF). This method has been increasingly popular because it is robust to misspecification of a vector autoregression (VAR) model. The IRF is estimated as a coefficient on an exogenous shock in a regression for each forecasting horizon, without estimating a set of coefficients in the VAR model for all

\footnotetext{
${ }^{8}$ The effect of an inflation shock on public debt could be smaller if the higher inflation is associated with a shortening of debt maturity, as suggested by Abbas et al. (2014).
} 
forecasting horizons (Teulings and Zubanov 2014). Furthermore, the local-projections method easily accommodates flexible specifications (e.g. non-linear specification).

Following Auerbach and Gorodnichenko (2017), our baseline specification is as follows:

$y_{i, t+h}=\sum_{k=0}^{K} \phi_{k}^{(h)} \Delta \pi_{i, t-k}+\sum_{k=1}^{K} \psi_{k}^{(h)} y_{i, t-k}+\sum_{k=1}^{K} \beta_{k}^{(h)} X_{i, t-k}+\alpha_{i}^{(h)}+\kappa_{t}^{(h)}+\varepsilon_{i t h}$

where $y_{i, t}$ is debt-to-GDP ratio, $\Delta \pi_{i, t}$ is inflation shock (identified by alternative methods below), $X_{i, t}$ is control variables (lagged GDP growth, lagged GDP deflator, lagged primary balance to GDP ratio, lagged long-term interest rates), $\alpha_{i}$ is country fixed effect, $\kappa_{t}$ is time fixed effect, and $\varepsilon_{i t h}$ is error term in a country $i=1, \ldots, N$ at a time $t=1, \ldots, T$. Impulse response to $\Delta \pi_{i, t}$ is constructed as $\left\{\phi_{0}^{(h)}\right\}_{h=0}^{H}$ estimated from a sequence of OLS regressions through horizon $h$.

\section{Identification of inflation shocks}

We need to identify shocks outside the model, unlike VAR. In the context of the local projection, there are only limited studies which identify an inflation shock. We try the following three alternative methods to identify inflation shocks: (1) residuals from an estimated Phillips curve, (2) forecast revisions, and (3) high inflation or deflation defined by certain thresholds.

\section{(1) Residuals from estimated Phillips curve}

Some previous studies on the local projection identify shocks to a variable using residual series from its own forecasting equation. ${ }^{9}$ In the context of inflation shocks, the residual series from an estimated Phillips curve could be reasonable. Following International Monetary Fund (2016), we estimate the standard hybrid new Keynesian Phillips curve as below:

$$
\pi_{i, t}=\beta_{1 i} \pi_{i, t+1}^{e}+\left(1-\beta_{1 i}\right) \pi_{i, t-1}+\beta_{2 i} G A P_{i, t-1}+\mu_{i}+\theta_{t}+u_{i t}
$$

where $\pi_{i, t}$ is the annual inflation rate, $\pi_{i, t+1}^{e}$ is the 1 year-ahead inflation expectation, $G A P_{i, t-1}$ is the GDP gap, $\mu_{i}$ is country fixed effect, $\theta_{t}$ is time fixed effect, and $u_{i t}$ is an error term. The degree of anchoring expectations, $\beta_{1 i}$, and the slope of the Philips curve, $\beta_{2 i}$, can be different across countries. To obtain a proxy of $\Delta \pi_{i, t}$ in the local projection model (1), we take the inflation shock as $\hat{u}_{i t}$ from the above equation (2).

\footnotetext{
${ }^{9}$ For example, Sekine and Tsuruga (2018) identify commodity price shocks using residual series from its their own forecasting equations.
} 


\section{(2) Forecast revisions}

The economic forecasts by the private sector, government, or international organizations have been used to identify shocks in many studies on the local projection. For instance, Auerbach and Gorodnichenko $(2013,2017)$ calculate the forecast error, using the OECD Economic Outlook, to identify government spending shocks. Similarly, we use the IMF WEO to identify inflation shocks as below:

$$
\Delta \pi_{i, t}=\pi_{i, t}-\pi_{i, t}^{e}
$$

Where $\Delta \pi_{i, t}$ is the difference between the current inflation rate $\pi_{i, t}$ and previously-projected inflation rate $\pi_{i, t}^{e}$ in the WEO. ${ }^{10}$

\section{(3) High inflation or deflation}

Some previous studies identify inflation or deflation shocks simply using dummy variables defined by certain thresholds. ${ }^{11}$ This identification is relatively simple and transparent. Moreover, it can naturally distinguish between inflation and deflation shocks and thus allows for the possibility of asymmetric impacts of inflation and deflation shocks on the public debtto-GDP ratio. The inflation and deflation shocks are defined as below: $D_{1}$ is a dummy variable that is equal to 1 if the inflation rate is larger than 3 and otherwise, $D_{1}$ is $0 . D_{2}$ is a dummy variable that is equal to 1 if the inflation shock is negative, and otherwise, $D_{2}$ is 0 .

$$
\begin{aligned}
y_{i, t+h}= & \sum_{k=0}^{K} \phi_{1 k}^{(h)} D_{1} \pi_{i, t-k}+\sum_{k=0}^{K} \phi_{2 k}^{(h)} D_{2} \pi_{i, t-k}+\sum_{k=1}^{K} \psi_{k}^{(h)} y_{i, t-k}+ \\
& \sum_{k=1}^{K} \beta_{k}^{(h)} X_{i, t-k}+\alpha_{i}^{(h)}+\kappa_{t}^{(h)}+\varepsilon_{i t h}
\end{aligned}
$$

\section{Data}

As in the simulation approach, 19 advanced economies are included in the sample. We use the data as consistently as possible with the simulation approach. Macro variables such as GDP, deflator, public debt, primary balance, and long-term interest rate are drawn from the OECD. For the identification of inflation shocks, we also use the GDP gap (estimated by OECD) and the WEO Projection data. For the analysis of debt maturity below, we use the average maturity data based on OECD Sovereign Borrowing Outlook ${ }^{12}$. We construct an unbalanced panel from 1997 to 2017. For quarterly data, we made seasonal adjustments and interpolation as needed.

\footnotetext{
${ }^{10}$ We use the difference between the projections in April WEO and October WEO for the current year.

${ }^{11}$ For example, Afonso and Jalles (2019) define a "deflation" variable which can take the form of either negative inflation rate or a dummy variable taking the value 1 when the inflation rate is negative.

${ }^{12}$ Missing data are replaced with the interpolation using data in the period before and after.
} 


\section{B. Main results}

The results of the baseline specification (1) are shown in Figure 4.1. The responses of the public debt to GDP ratio to inflation shocks identified by all the three methods above are significantly negative. The size and persistence vary greatly depending on the identified shocks, but the initial responses are around 1 percentage point and the peak responses are somewhere around 2 to 3 percentage points for all identification methods using annual data (panels A and $\mathrm{C}$ ). When we use the quarterly data (panel B), the response to the inflation shock identified by the residual from an estimated Philips curve is smaller (the initial response is around 0.5 percentage points and the peak response is around 1 percentage point) ${ }^{13}$. Compared with the results of the simulation approach, these responses are generally larger and more persistent. This may imply that some secondary effects through real GDP or primary balance are captured in the estimation approach but not in the simulation approach. Another possibility is that the shocks identified in the estimation approach have somewhat persistent effects while the shock in the simulation approach is purely temporary.

Regarding the responses to the high inflation and deflation shocks identified by certain thresholds (the third identification method), we can see clear asymmetry between the impacts of inflation and deflation shocks and the latter is much larger than the former (panel D). This is probably because the downward adjustment of nominal interest rates is more sluggish (downward rigidity) in response to a deflation shock.

\section{Robustness checks}

Following the literature on the local projection, we examine two types of robustness checks:(1) controlling the lead variables and (2) dealing with "Nickel bias" for short time-series dimension.

(1) Controlling the lead variables. According to Teulings and Zubanov (2014), the local projection without controlling for the shocks in the regressors between periods $t$ and $t+h$ when estimating the impulse response at horizon $h$ could bias the impulse response. For the robustness check, we add the lead variable for the inflation shock to the baseline specification.

Figure 4.2 shows the results, which are broadly in line with the baseline results.

(2) Nickel bias for annual data. Nickell (1981) points out that the presence of lagged dependent variables in panel estimations would lead to bias if the serial correlation of the dependent variables is high and the time-series dimension is short. While the time-series dimensions of quarterly data are relatively larger than the cross-sectional dimension $(\mathrm{N}=19)$, those of annual data is shorter. Hence, as the robustness check, we exclude the fixed-effects term when we use the annual data.

\footnotetext{
13 The coefficient on the inflation shock tends to be smaller in the case using quarterly data because the quarterly inflation shocks identified by the residual tend to be larger than the annual inflation shocks while the size of the debt-to-GDP ratio is the same between the cases using quarterly and annual data.
} 
Figure 4.3 shows the results, which are in line with the baseline results for the initial impact although the long-run impacts are larger.

\section{Comparison between short vs long maturity}

In addition to the baseline specification, we shed light on how the debt maturity may influence the impact of inflation shock on debt-to-GDP ratio. We consider the following modification of specification (1):

$$
\begin{aligned}
y_{i, t+h}= & \sum_{k=0}^{K} \phi_{1 k}^{(h)} D_{1} \Delta \pi_{i, t-k}+\sum_{k=0}^{K} \phi_{2 k}^{(h)} D_{2} \Delta \pi_{i, t-k}+\sum_{k=1}^{K} \psi_{k}^{(h)} y_{i, t-k}+ \\
& \sum_{k=1}^{K} \beta_{k}^{(h)} X_{i, t-k}+\alpha_{i}^{(h)}+\kappa_{t}^{(h)}+\varepsilon_{i t h}
\end{aligned}
$$

where $D_{1}$ is a dummy variable that is equal to 0 if the average maturity of government debt is below 6 years. Otherwise, $D_{1}$ is $1 . D_{2}$ is a dummy variable that is equal to 1 if the average maturity of government debt is above 6 years. Otherwise, $D_{2}$ is 0 .

Figure 4.4 shows the results when we split the sample between countries with short debt maturity and those with long debt maturity. If the average maturity of government debt is below 6 years, the corresponding countries belong to the group with short debt maturity and if it is above 6 years, they belong to the group with long debt maturity.

The impacts of inflation shocks are generally larger in the countries with long debt maturity than those with short debt maturity. However, the difference between them is not necessarily large, which is consistent with the result in the simulation approach.

\section{CONCLUSION}

We have quantitatively assessed the effects of inflation shocks on the public debt-to-GDP ratio in 19 advanced economies using simulation and estimation approaches. Our simulations based on the debt dynamics equation and our estimations of impulse responses by local projections both suggest that a temporary 1 percentage point shock to inflation rate reduces the debt-toGDP ratio by about 0.5 to 1 percentage points. Our results also suggest that the impact is larger and more persistent when the debt maturity is longer, but the difference from the benchmark case is not that significant. These results imply that modestly higher inflation, even if accompanied by some financial repression, could reduce public debt burden only marginally in many advanced economies. One policy implication would be that monetary policy or financial repression alone cannot help achieving a significant reduction of public debt levels. If we fully relied on it, very high or hyper-inflation would likely be needed, which clearly entail other more salient costs. 
The effects of other shocks, such as growth and fiscal consolidation shocks, on the debt-toGDP ratio, could be much larger than the effect of inflation shock, as suggested by some previous studies of accounting exercise cited in Section II (e.g. Hall and Sargent, 2011). However, identification of policies and strategies to generate sufficient and sustainable growth and primary balance to meaningfully reduce public debt are also challenging, and would be an important direction for future research. 
Table 1: Recent studies on the effects of inflation shock on public debt

\section{(a) Simulations}

\begin{tabular}{|c|c|c|c|c|}
\hline paper & approach & data & inflation shock & $\begin{array}{c}\text { effect on debt/GDP } \\
\text { <if 1pp shock> }\end{array}$ \\
\hline Akitoby, Komatsuzaki, Binder (2014) & debt equation & $\begin{array}{l}\text { G7 macro (WEO), } \\
2012-17\end{array}$ & $\begin{array}{l}\text { persistent shock raising } \\
\text { inflation to } 6 \%\end{array}$ & $\begin{array}{l}14 p p<3.3 p p>\text { decrease } \\
\text { in } 5 \text { years }\end{array}$ \\
\hline Hilscher, Raviv, Reis (2017) & debt equation & $\begin{array}{l}\text { US bond, option } \\
\text { prices }\end{array}$ & $\begin{array}{l}\text { th percentile of } \\
\text { inflation risk }(>3 \%)\end{array}$ & $2.7 p p<0.9 p p>$ decrease \\
\hline Equiza-Goni (2016) & debt equation & Euro area bonds & $\begin{array}{l}\text { persistent 1pp increase } \\
\text { in inflation }\end{array}$ & $\begin{array}{l}\text { 4.2pp decrease } \\
\text { on impact }\end{array}$ \\
\hline Aizanman and Marion (2011) & simple formula & $\begin{array}{l}\text { US bond maturity } \\
\text { at } 2009\end{array}$ & $\begin{array}{l}\text { persistent 3pp increase } \\
\text { in inflation }\end{array}$ & $\begin{array}{l}12 p p<4 p p>\text { decrease } \\
\text { on impact }\end{array}$ \\
\hline End et al. (2015) & model simulation & Euro area, 2015-16 & $\begin{array}{l}\text { persistent 2pp increase } \\
\text { in inflation }\end{array}$ & $\begin{array}{l}3 p p<1.5 p p>\text { decrease } \\
\text { in } 5 \text { years }\end{array}$ \\
\hline Krause and Moyen (2016) & DSGE simulation & US, 2008-13 & $\begin{array}{l}\text { persistent 4pp increase } \\
\text { in inflation target }\end{array}$ & $\begin{array}{l}10 p p<2.5 p p>\text { decrease } \\
\text { in } 10 \text { years }\end{array}$ \\
\hline \multirow[t]{2}{*}{ Our paper } & \multirow[t]{2}{*}{ debt equation } & \multirow[t]{2}{*}{$\begin{array}{l}19 \text { AE's macro } \\
\text { (WEO), 2017-22 }\end{array}$} & $\begin{array}{l}\text { persistent shock raising } \\
\text { inflation to } 6 \%\end{array}$ & $\begin{array}{l}10 p p<2.4 p p>\text { decrease } \\
\text { in } 5 \text { years }\end{array}$ \\
\hline & & & $\begin{array}{l}\text { temporary } 1 \mathrm{pp} \text { increase } \\
\text { in inflation }\end{array}$ & $\begin{array}{l}0.7 p p \text { decrease } \\
\text { on impact }\end{array}$ \\
\hline
\end{tabular}

\section{(b) Estimations}

\begin{tabular}{|l|l|l|l|l|}
\hline \multicolumn{1}{|c|}{ paper } & approach & data & inflation/deflation shock & \multicolumn{1}{c|}{$\begin{array}{c}\text { effect on debt/GDP } \\
<\text { if 1pp shock }>\end{array}$} \\
\hline Afonso and Jalles (2019) & local projection & 17 AE's, 1870-1914 & deflation dummy (=1) & $\begin{array}{l}\text { 1pp increase } \\
\text { on impact }\end{array}$ \\
\cline { 2 - 2 } & panel regression & & 1pp decrease in inflation & $\begin{array}{l}0.23-0.33 p p \text { increase } \\
\text { on impact }\end{array}$ \\
\hline End et al. (2015) & panel regression & 21 AE's, 1851-2013 & 1pp increase in inflation & $\begin{array}{l}0.15 p p \text { decrease } \\
\text { on impact }\end{array}$ \\
\hline Cherif and Hasanov (2018) & VAR & US, 1980-2007 & $\begin{array}{l}0.22 p p \text { increase in } \\
\text { inflation }\end{array}$ & $\begin{array}{l}\text { 0.3pp <1.4pp }>\text { decrease } \\
\text { on impact }\end{array}$ \\
\hline Our paper & local projection & 19 AE's, 1995-2017 & 1pp increase in inflation & $\begin{array}{l}\text { 0.5-1pp decrease } \\
\text { on impact }\end{array}$ \\
\hline
\end{tabular}


Figure 1: Responses to 1pp temporary inflation shock

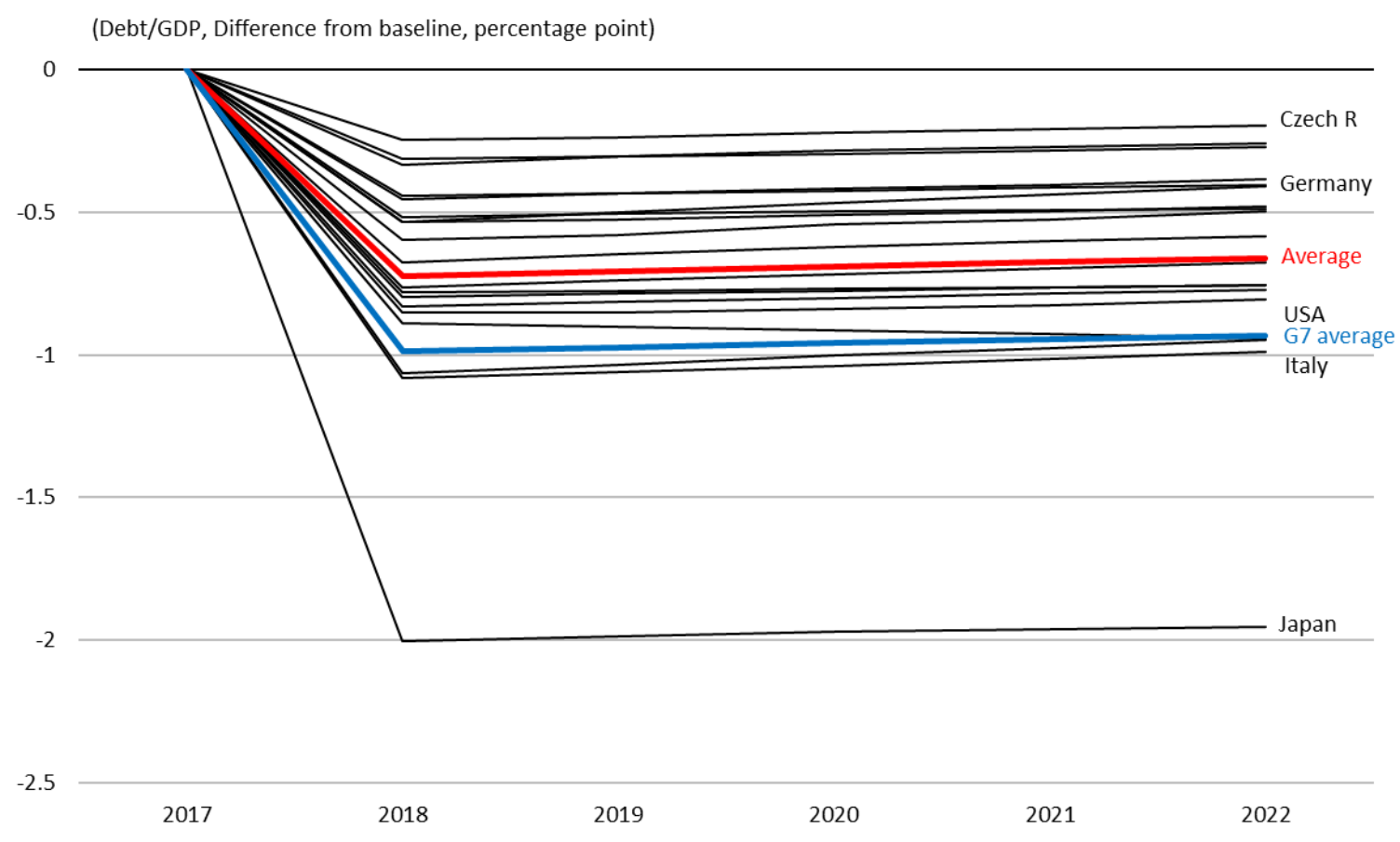


Figure 2: Cross-country differences

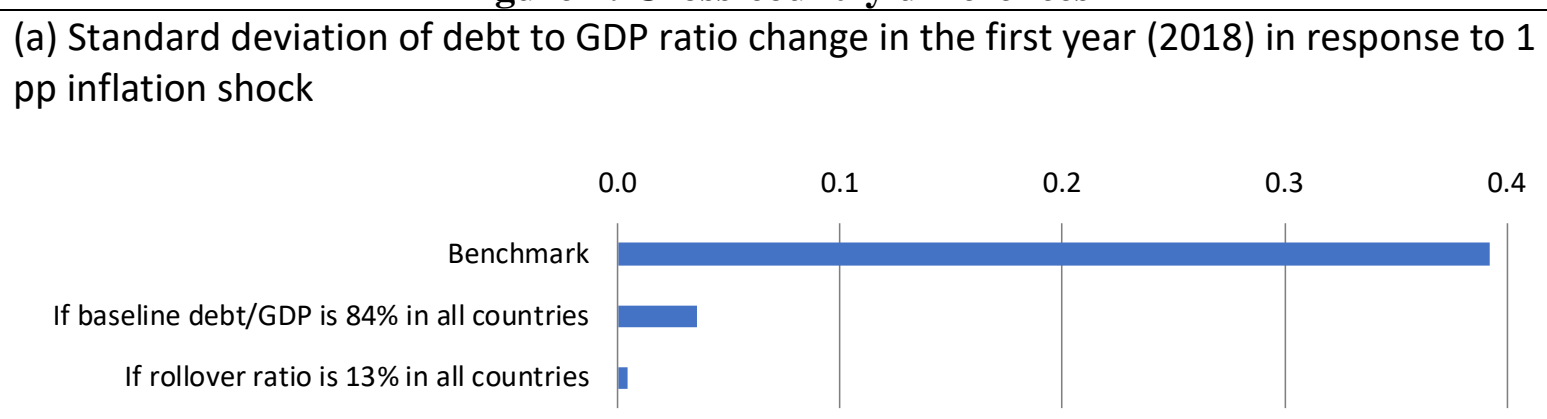

(b) Debt to GDP ratio change in the first year (2018) in response to $1 \mathrm{pp}$ inflation shock

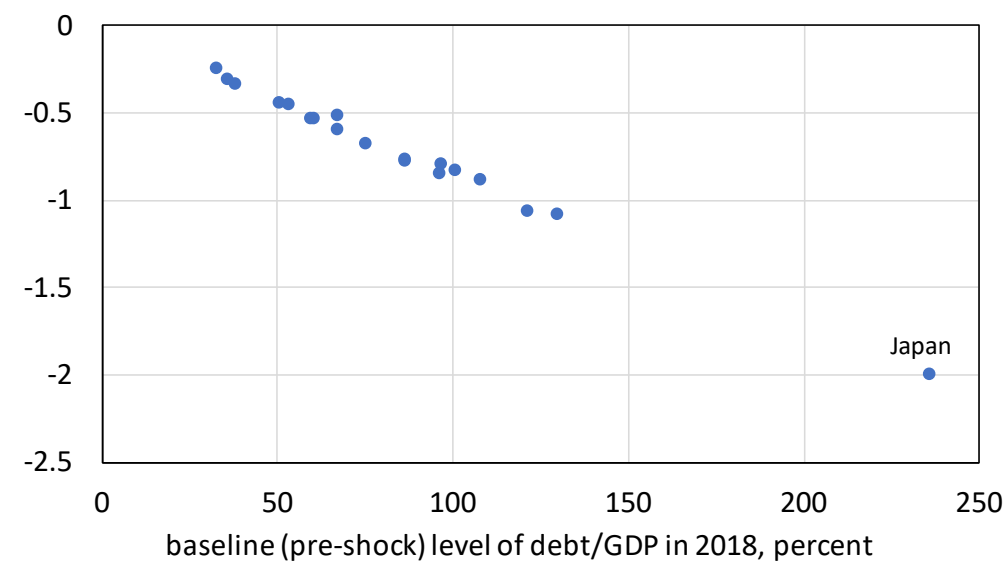

(c)Debt to GDP ratio change in the first year (2018) in response to $1 \mathrm{pp}$ inflation shock, if baseline debt to GDP ratio is 84 percent in all countries

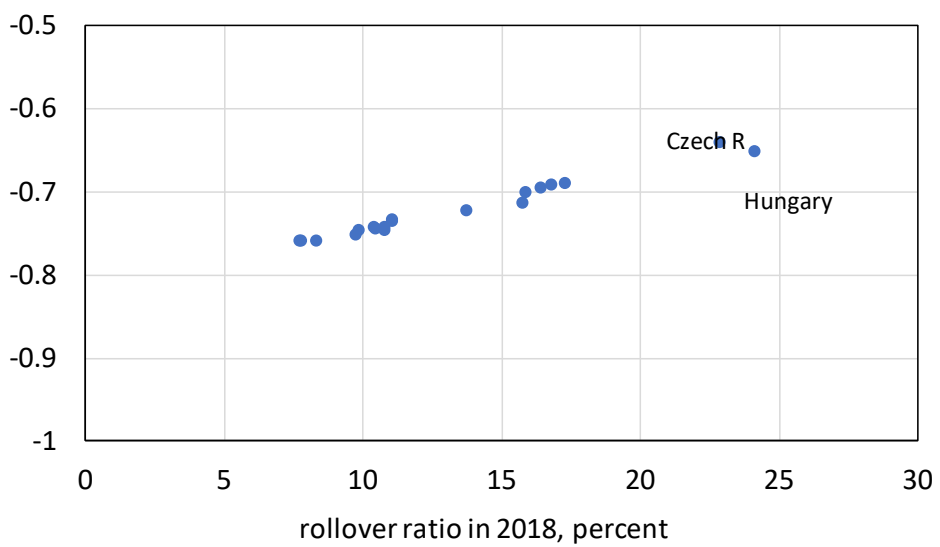


Figure 3: Responses to 1pp temporary inflation shock (Financial repression cases)

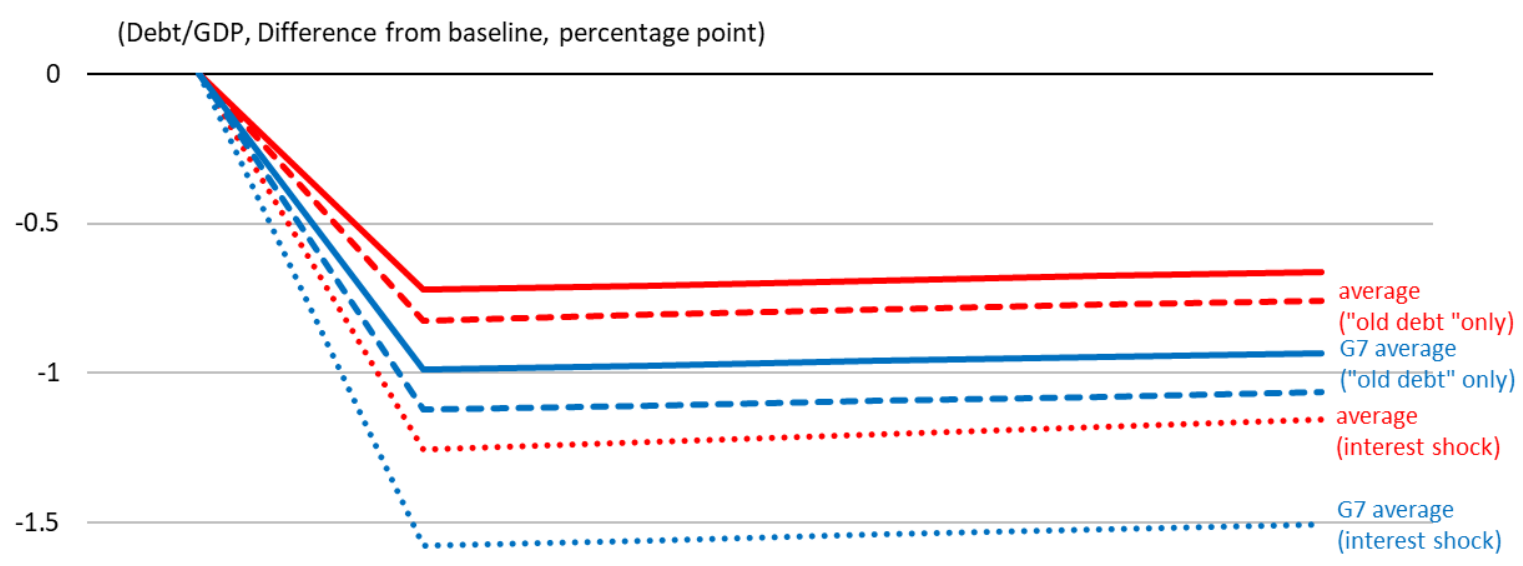

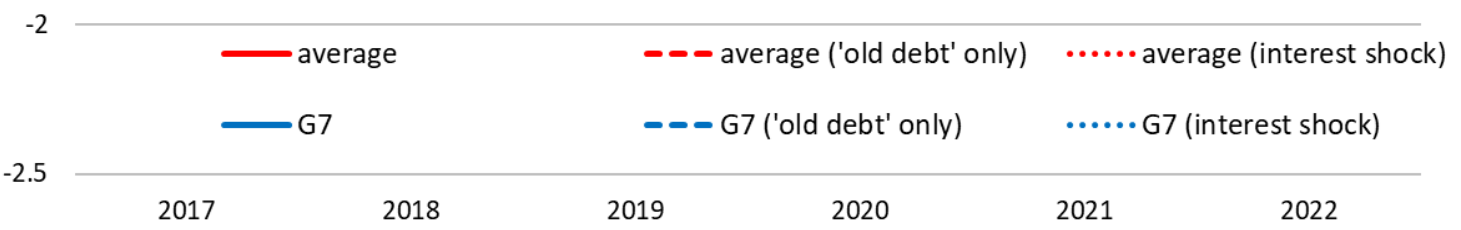


Figure 4.1. Responses to 1 pp identified inflation shocks

A. Residuals from Philips curve (Identification1, Annual data)

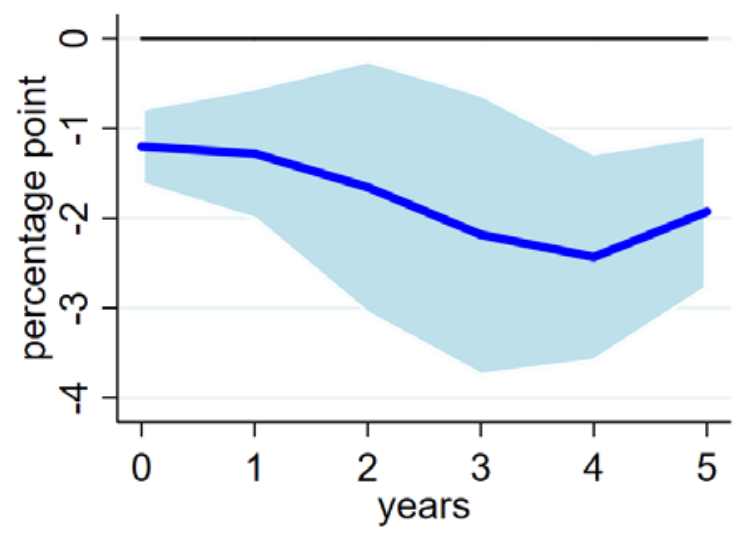

B. Residuals from Philips curve (Identification1, Quarterly data)

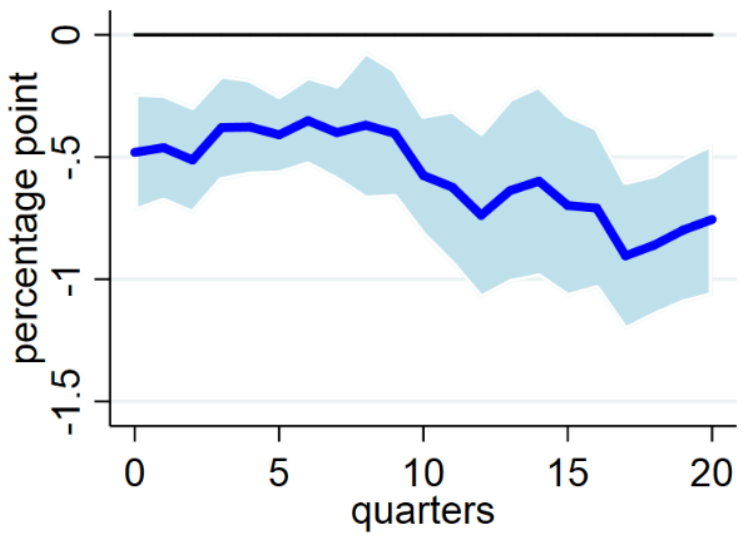

C. WEO forecast revisions (Identification2, Annual data)

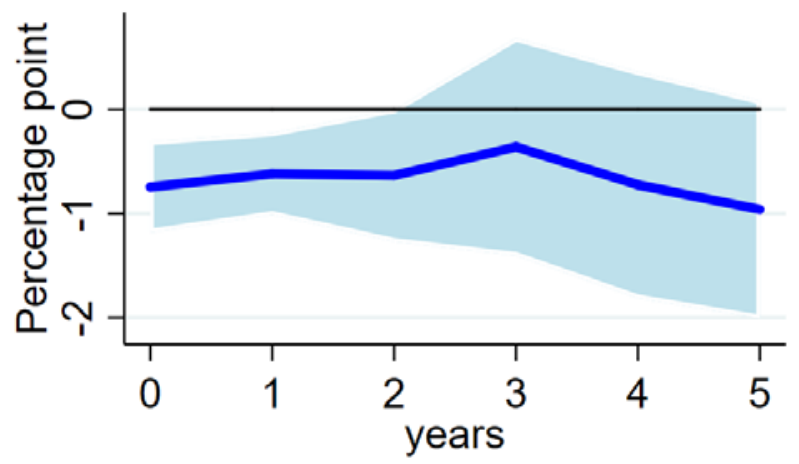

D. High inflation or deflation (Identification3, Annual data)
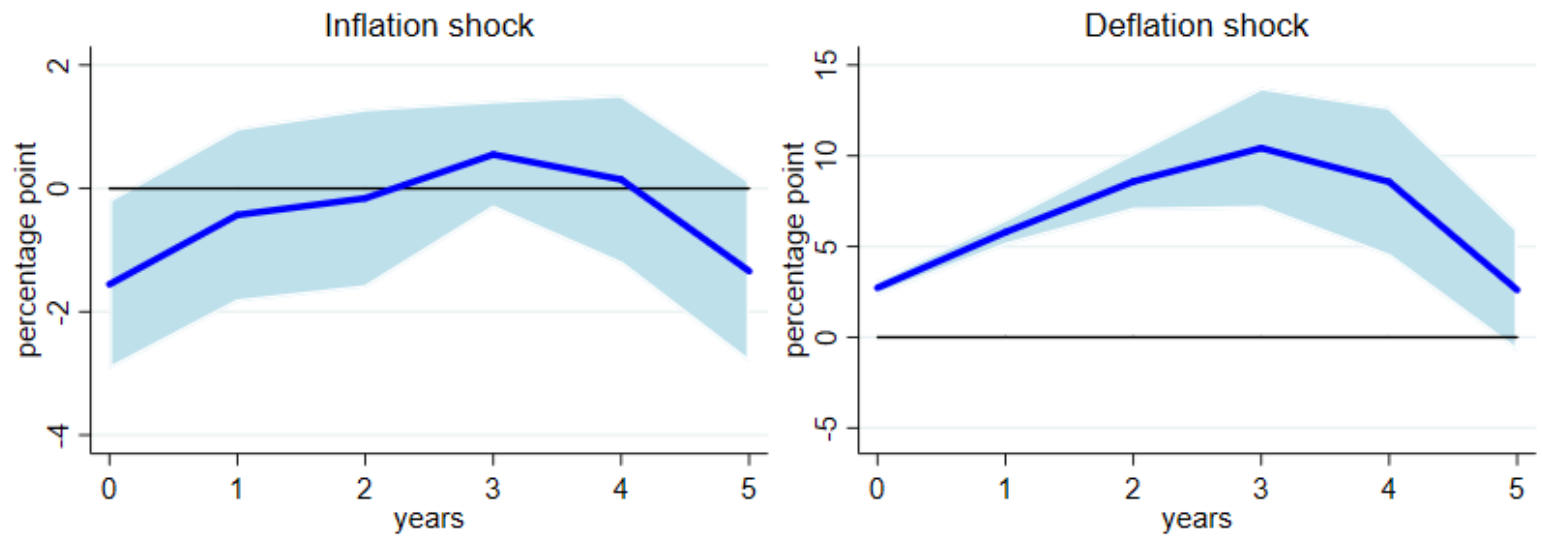

Note: 90 \% confidence bands are constructed using Driscoll-Kraay robust standard errors. 
Figure 4.2: Responses to 1 pp identified inflation shocks (including lead variables)

A. Residuals from Philips curve (Identification1, annual data)

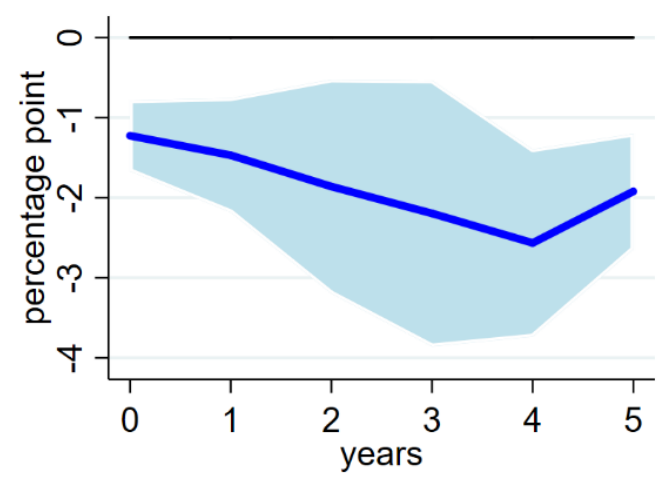

C. WEO forecast revisions (Identification2, annual data)

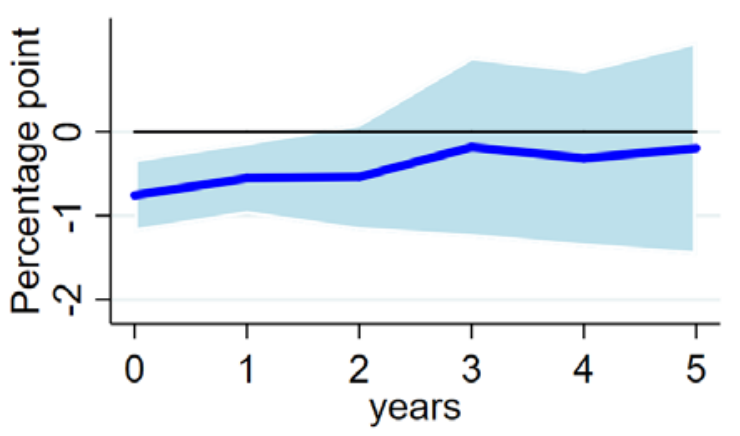

B. Residuals from Philips curve (Identification1, Quarterly data)

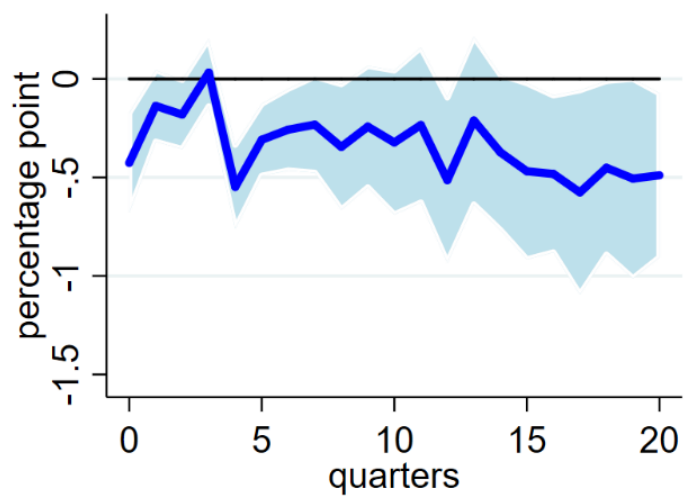

Note: 90 \% confidence bands are constructed using Driscoll-Kraay robust standard errors.

Figure 4.3: Responses to $1 \mathrm{pp}$ identified inflation shocks (excluding time and country fixed effects)

A. Residuals from Philips curve (Identification1, annual data)

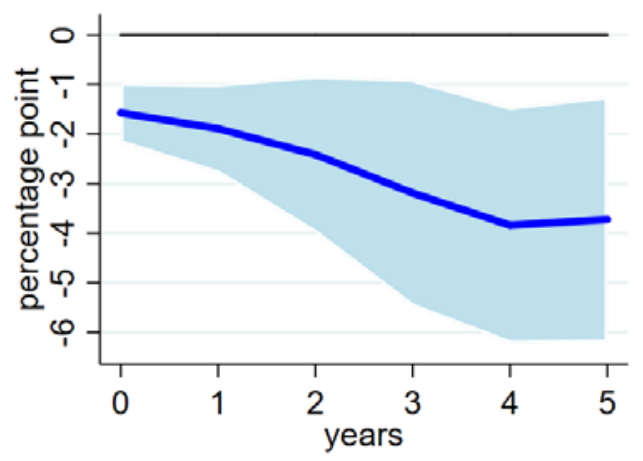

B. WEO forecast revisions (Identification2, annual data)

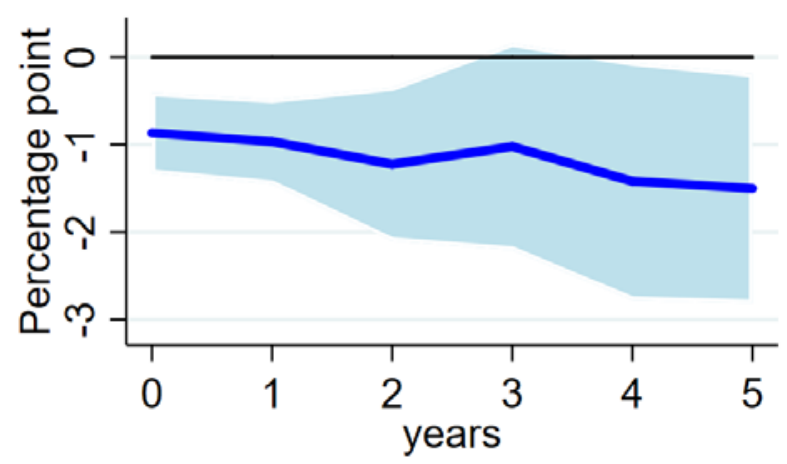

Note: 90 \% confidence bands are constructed using Driscoll-Kraay robust standard errors. 
Figure 4.4: Responses to 1 pp identified inflation shocks (short vs long maturity)

A. Residuals from Philips curve (Identification1, annual data)
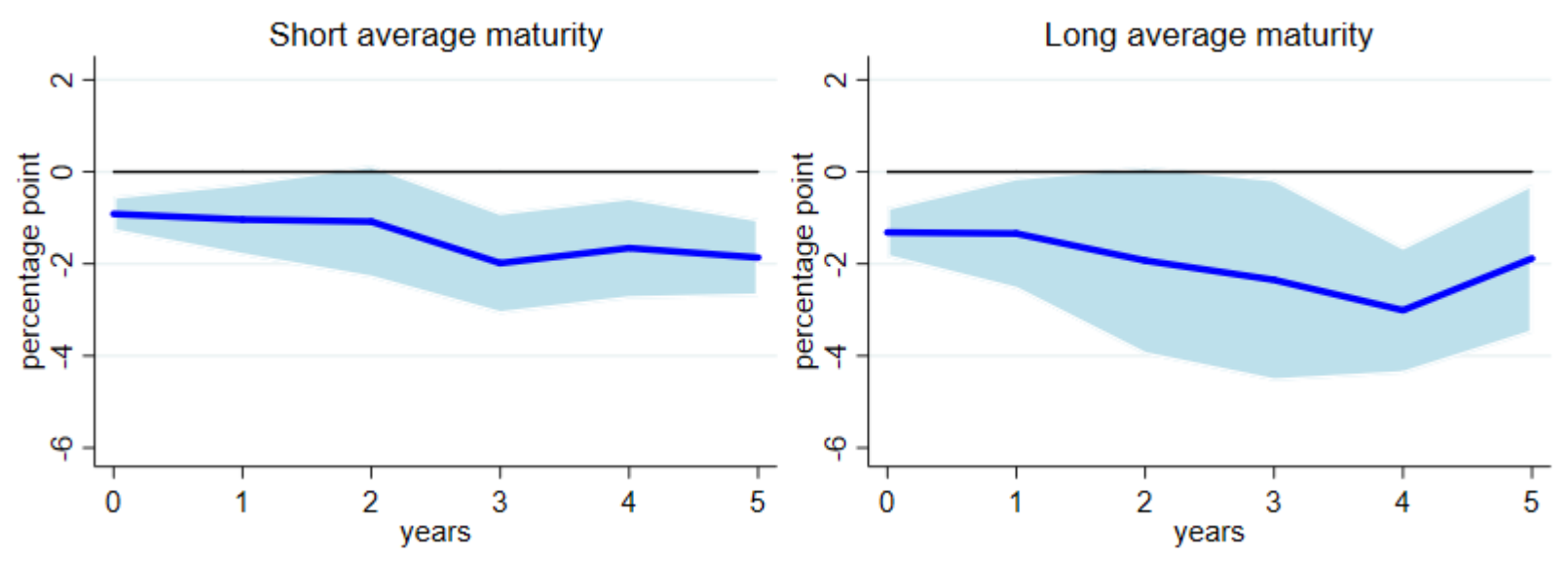

B. Residuals from Philips curve (Identification1, quarterly data)
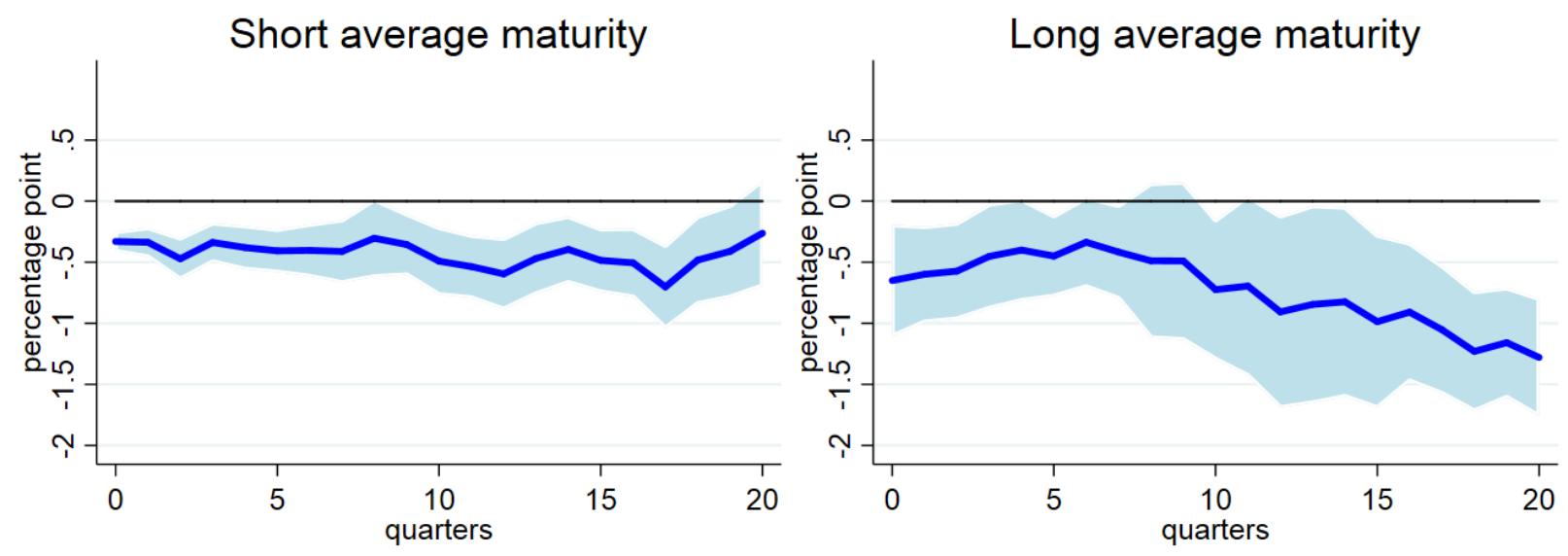

C. WEO forecast revisions (Identification2, annual data)
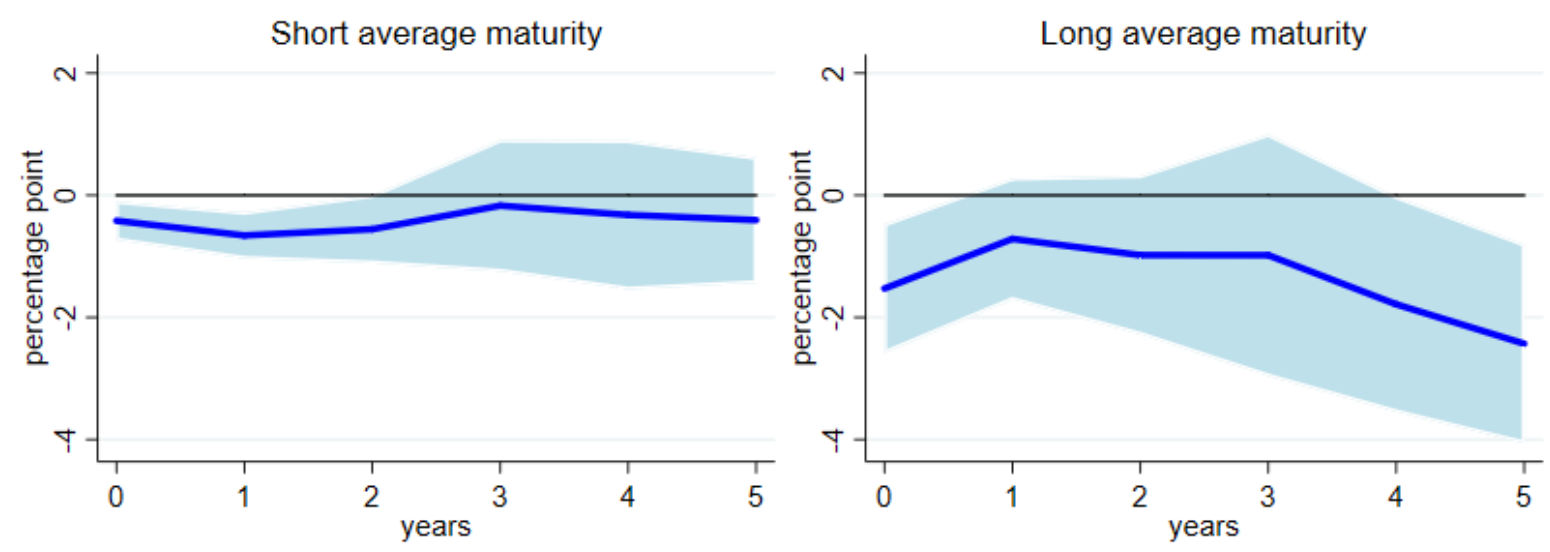


\section{Appendix: Persistent Inflation Shocks}

Results are summarized in Table 2. The persistent inflation shock results in a debt reduction of 10 percentage points for 19 advanced economies average and 15 percentage points for G7 average. The higher effect on G7 is mainly due to the higher level of public debt at the start of the simulation, especially Italy and Japan. The result on G7 is broadly similar to the result in Akitoby et al. (2014). One exception is Canada, for which the debt reduction effect is significantly higher in the present paper than Akitoby et al. (2014): while the persistent inflation shock that increases inflation to 6 percent for five years reduces the debt-to-GDP ratio by 5 percentage points in Akitoby et al. (2014), the same shock reduces the debt-to-GDP ratio by 10 percentage point in the present paper. This is essentially due to the change in data source for debt maturity. While Akitoby et al. (2014) used an OECD database on central government that was subsequently discontinued, the present paper uses BIS data that encompasses general government, which is consistent with our measurement of the public debt-to-GDP ratio at the general government level. Since Canada's subnational governments are very large, this change in data source changes the share of medium and long-term debt more significantly than other countries.

Table 2: 6\% inflation scenario (persistent shock)

\begin{tabular}{|c|c|c|c|c|c|c|c|}
\hline & 20 & & \multicolumn{2}{|c|}{ 2018-22 } & \multicolumn{3}{|c|}{2022} \\
\hline & \multicolumn{2}{|c|}{ gross debt/GDP } & \multicolumn{2}{|c|}{ inflation } & \multicolumn{3}{|c|}{ gross debt/GDP } \\
\hline & total & MT-LT & WEO & simulation & WEO & simulation & difference \\
\hline Canada & 89.7 & 78.9 & 2.1 & 6.0 & 76.4 & 66.3 & -10.1 \\
\hline France & 97.0 & 89.5 & 1.4 & 6.0 & 91.6 & 78.2 & -13.4 \\
\hline Germany & 64.1 & 59.2 & 2.0 & 6.0 & 45.5 & 39.0 & -6.4 \\
\hline Italy & 131.5 & 124.7 & 1.3 & 6.0 & 119.3 & 104.2 & -15.1 \\
\hline Japan & 236.4 & 210.0 & 0.8 & 6.0 & 230.7 & 195.6 & -35.1 \\
\hline United Kingdom & 87.0 & 82.8 & 1.7 & 6.0 & 83.6 & 71.2 & -12.5 \\
\hline United States & 107.8 & 96.4 & 2.0 & 6.0 & 115.2 & 101.6 & -13.6 \\
\hline G7 average & 116.2 & 105.9 & 1.6 & 6.0 & 108.9 & 93.7 & -15.2 \\
\hline $19 \mathrm{AE}$ 's average & 86.3 & 79.4 & 1.7 & 6.0 & 77.5 & 67.2 & -10.3 \\
\hline
\end{tabular}




\section{References}

Abbas, A., N. Belhocine, A. El-Ganainy and M. Horton (2011) "Historical Patterns and Dynamics of Public Debt-Evidence from a New Database,” IMF Economic Review 59 (4), 717-742.

Abbas, A., L. Blattner, M. De Broeck, A. El-Ganainy and M. Hu (2014) "Sovereign Debt Composition in Advanced Economies: A Historical Perspective," IMF Working Paper, WP/14/162.

Afonso, A. and J. T. Jalles (2019), “The Fiscal Consequences of Deflation: Evidence from the Golden Age of Globalization,” The Quarterly Review of Economics and Finance, forthcoming.

Aizenman, J. and N. Marion (2011), “Using Inflation to Erode the US Public Debt,” Journal of Macroeconomics, 33, 524-541.

Akitoby, B., T. Komatsuzaki, and A. Binder (2014), "Inflation and Public Debt Reversals in the G7 Countries,” IMF Working Paper, WP/14/96.

Auberbach, A. and J. Gorodnichenko (2013), “Fiscal Multipliers in Recession and Expansion”, in Fiscal Policy after the Financial Crisis, Alberto Alesina and Francesco Giavazzi, eds., University of Chicago Press.

Auberbach, A. and J. Gorodnichenko (2017), "Fiscal Stimulus and Fiscal Sustainability,” NBER Working Paper 23789.

Best, T., O. Bush, L. Eyraud, and M. Belen Sbrancia (2019), "Reducing Debt Short of Default”, in Sovereign Debt: A Guide for Economists and Practitioners, S Ali Abbas, Alex Pienkowski, and Kenneth Rogoff, eds.

Blanchard, O. (2019), "Public Debt and Low Interest Rates,” American Economic Review, 109(4): 1197-1229.

Cherif, R. and F. Hasanov (2018), "Public Debt Dynamics: the Effects of Austerity, Inflation, and Growth Shocks,” Empirical Economics, 54, 1087-1105.

Cochrane, J. H. (2011). “Understanding Policy in the Great Recession: Some Unpleasant Fiscal Arithmetic,” European Economic Review, 55(1): 2-30.

Davig, T., E. M. Leeper, and T. B. Walker (2011) “Inflation and the Fiscal Limit,” European Economic Review, 55(1): 31-47.

Doepke, M. and M. Schneider (2006) "Inflation and the Redistribution of Nominal Wealth," Journal of Political Economy, 114(6): 1069-97.

End, N., S. J.-A. Tapsoba, G. Terrier, and R. Duplay (2015), “Deflation and Public Finances: Evidence from the Historical Records,” IMF Working Paper, WP/15/176.

Equiza-Goñi, J. (2016), “Government Debt Maturity and Debt Dynamics in Euro Area Countries,” Journal of Macroeconomics, 49, 292-311.

Giannitsarou, C. and A. Scott (2008), “Inflation Implications of Rising Government Debt," NBER International Seminar on Macroeconomics 2006, 393-442. 
Hall, G. J. and T. J. Sargent (2011), "Interest Rate Risk and Other Determinants of Post-WWII Us Government Debt/GDP Dynamics,” American Economic Journal: Macroeconomics, 3, July 2011, 192-214.

Hilscher, J., A. Raviv, and R. Reis (2017), "Inflating Away the Public Debt? An Empirical Assessment,” earlier version in NBER Working Paper, 20339, July 2014.

International Monetary Fund (2016), "Global Disinflation in an era of Constrained Monetary Policy,” World Economic Outlook, October 2016.

International Monetary Fund (2018), "Saving for a Rainy Day,” Fiscal Monitor, Chapter 1, April 2018.

Jordà, O (2005), "Estimation and Inference of Impulse Response by Local Projections", American Economic Review 95(1): 161-182.

Khan, M., and Abdelhak S. Senhadji (2001), "Threshold Effects in the Relationship Between Inflation and Growth”, IMF Staff Papers 48(1): 1-21.

Krause, M. U. and S. Moyen (2016), “Public Debt and Changing Inflation Targets,” American Economic Journal: Macroeconomics, 8(4), 142-176.

Nickel, S. (1981), "Biases in Dynamic Models with Fixed Effects”, Econometrica 49(6), 141726.

Reinhart, C. M. and M. B. Sbrancia (2015), “The Liquidation of Government Debt,” Economic Policy, 30(82), March 2015, 291-333.

Rogoff, K. (2013), “Inflation is Still a Lesser Evil,” Project Syndicate, June 6, 2013.

Sekine, A., and T. Tsuruga (2018), "Effects of Commodity Price Shocks on Inflation: a CrossCountry Analysis”, Oxford Economic Papers 70(4): 1108-1135.

Sims, C. (2016) "Fiscal Policy, Monetary Policy and Central Bank Independence,” Luncheon Address, Designing Resilient Monetary Policy Frameworks for the Future, Economic Policy Symposium Proceedings, Federal Reserve Bank of Kansas City.

Teulings C., and N. Zubanov (2014), "Is Economic Recovery a Myth? Robust Estimation of Impulse Responses”, Journal of Applied Econometrics 29: 497-514. 